\title{
Conductometric method development and validation to estimate acamprosate calcium in API and marketed formulation
}

\author{
Rahul K. Yadav ${ }^{1}$ (D), Meenaxi M. Maste ${ }^{1 *}$ (D), Shailendra S. Surywanshi ${ }^{1}$ (D), Utkarsh Shastri² \\ ${ }^{1}$ Department of Pharmaceutical Chemistry, KLE College of Pharmacy, KLE Academy of Higher Education and Research, Belagavi, India. \\ ${ }^{2}$ Department of Pharmaceutics, KLE College of Pharmacy, KLE Academy of Higher Education and Research,, Belagavi, India.
}

\begin{tabular}{l}
\hline ARTICLE INFO \\
\hline Received on: 08/04/2021 \\
Accepted on: 22/06/2021 \\
Available online: 03/11/2021 \\
\hline Key words: \\
Acamprosate calcium, \\
alcohol dependence, electrical \\
conductivity, ICH guidelines, \\
quality control.
\end{tabular}

\begin{abstract}
A simple, precise, rapid, low-cost conductometric method was developed and validated for the estimation of acamprosate calcium in pure and pharmaceutical formulation. The present research work utilized distilled water as a vehicle to prepare different concentrations of acamprosate calcium. The electrical conductivity of resulting solutions was measured by using an electrical conductometer ELICO CM 183EC-TDS analyzer version 2.3. The validation parameters were carried out according to the International Conference on Harmonization Guidelines. The developed method showed a linear response between concentration ranges of 50 and $250 \mu \mathrm{g} / \mathrm{ml}$. The limit of detection and limit of quantification values were found to be 6.05 and $18.34 \mu \mathrm{g} / \mathrm{ml}$, respectively. The relative standard deviation observed in precision, ruggedness, and robustness was in the acceptable range. The recovery of the proposed method was in the range of $98 \%-105 \%$. The newly developed and validated conductometric method can be applied for the routine analysis of acamprosate calcium in pure and pharmaceutical formulation.
\end{abstract}

\section{INTRODUCTION}

Acamprosate calcium (calcium 3-acetamidopropane-1sulfonate; Figure 1) is a calcium salt of acetylhomotaurine which is used for the treatment of alcohol dependence, which acts by stabilizing the chemical balance in the central nervous system, by blocking glutaminergic N-methyl-D-aspartate receptors and activation of gamma-aminobutyric acid (GABA) type A receptors (Rhee et al., 2008a; Saivin et al., 1998; Zornoza et al., 2003). This drug is available since 1989 in the tablet strength of $333 \mathrm{mg}$ (Lipha Pharmaceuticals Inc., 2002). It is approved by the US Food and Drug Administration (FDA) as an antidipsotropic agent and is used to decrease alcohol hankering (Espino and Cruz, 2005). The chemical formula of acamprosate calcium is $\mathrm{C}_{10} \mathrm{H}_{20} \mathrm{~N}_{2} \mathrm{O}_{8} \mathrm{~S}_{2} \mathrm{Ca}$ with molecular weight $400.48 \mathrm{~g} / \mathrm{mol}$. The physical properties of

\section{*Corresponding Author}

Meenaxi M. Maste, Department of Pharmaceutical Chemistry, KLE

College of Pharmacy, KLE Academy of Higher Education and Research, Belagavi, India.

E-mail:menaimm@gmail.com<smiles>CC(=O)NCCCS(=O)(=O)[O-]</smiles><smiles>CC(=O)NCCCS(=O)(=O)[O-]</smiles>

Figure 1. Acamprosate calcium. 
this drug are white and odorless powder, which is freely soluble in water and insoluble in organic solvents like ethanol and dimethylformamide.

The literature survey reports on the capillary zone electrophoresis method (Blanchin et al., 2000; Fabre et al., 1999). The Liquid Chromatography mass spectrometry (LCMS) method for bioanalytical analysis, LC-fluorometric, and electrochemical detection was reported in human plasma, dog plasma, and urine (Chabenat et al., 1987, 1989; Ghosh et al., 2011; Girault et al., 1990; Hammarberg et al., 2010; Kanala et al., 2013; Rhee et al., 2008a; Rhee et al., 2008b; Xu et al., 2009). A few methods are developed and validated for organic acids by conductometric titration method (Umarov et al., 2020). Hence, no work has been reported on the electrical conductivity method for the quantitative estimation of acamprosate calcium. In this research, a new cost-effective, precise, and regression co-efficient on electrical conductivity method on acamprosate calcium in pure and marketed formulation is reported.

\section{MATERIALS AND METHODS}

\section{Instruments and apparatus}

An electrical conductivity meter (ELICO CM 183ECTDS analyzer version 2.3) was used for measuring electrical conductivity of solutions. An electronic analytical weighing balance (SARTORIUS) was used for weighing the analyte.

\section{Reagents and chemicals}

The active pharmaceutical ingredient of $98 \%$ purity of acamprosate calcium was procured from BMR Pharma and Chemicals, Hyderabad; tablet formulation was purchased from a local market of Belgaum, India. Distilled water was collected from Direct-Q UV water purification system from KLE College of Pharmacy.

\section{Method development}

The method was developed using an electrical conductivity meter using distilled water as a solvent. Various concentrations of acamprosate calcium in distilled water were prepared and electrical conductivity was measured. Different concentrations of analyte were observed and showed different values of electrical conductivity. In order to test the suitability of the developed method, the commercial tablet formulation of acamprosate calcium was analyzed.

\section{Preparation of stock solution and working standard solution}

Fifty milligram of the active pharmaceutical ingredient was dissolved in $50 \mathrm{ml}$ of a volumetric flask and the final volume was made with distilled water (stock solution $=1,000 \mu \mathrm{g} / \mathrm{ml}$ ); from the above solution, $0.5-2.5 \mathrm{ml}$ was pipetted and transferred in $10 \mathrm{ml}$ of a volumetric flask and the final volume was made with distilled water to obtain $50-250 \mu \mathrm{g} / \mathrm{ml}$ of pure acamprosate calcium.

\section{Method validation}

As per the International Conference on Harmonization (ICH) Guidelines Q2 (R1), the method was validated for various parameters like specificity, linearity, limit of detection (LOD), limit of quantification (LOQ), precision, ruggedness, accuracy, and assay.

\section{SPECIFICITY}

The specificity of the method was studied by measuring the conductance of a solvent as blank and the prepared standard solution of acamprosate calcium $(50 \mu \mathrm{g} / \mathrm{ml})$.

\section{LINEARITY}

The linearity method was developed by measuring the electrical conductivity of different concentrations of acamprosate calcium. Dilutions containing 50-250 $\mu \mathrm{g} / \mathrm{ml}$ acamprosate calcium were prepared and electrical conductivity was measured using electrical conductometer. The calibration curve was obtained by plotting the concentration versus electrical conductivity $(\mu \mathrm{s})$, and the correlation coefficient $\left(r^{2}\right)$ was found to be 0.9999 .

\section{LIMIT OF DETECTION/LIMIT OF QUANTIFICATION}

LOD is the lowest amount of analyte which can be detected but not quantified. It can be determined using following formula:

$$
L O D=3.3 \frac{\sigma}{S} .
$$

LOQ is the lowest amount of analyte which can be quantitatively determined as precision using the following formula:

$$
L O Q=10 \frac{\sigma}{S}
$$

where $\sigma=$ standard deviation;

$S=$ Slope of the calibration curve.

\section{PRECISION}

The precision was carried out in terms of intraday and interday. The electrical conductivity of three replicate solutions of acamprosate calcium at three different concentrations was measured, and \% Relative Standard Deviation (RSD) values of each solution for its electrical conductivity were measured.

\section{RUGGEDNESS}

Ruggedness was carried out by changing the analyst to check the reproducibility of standard results and the \%RSD was found to be less than $2 \%$.

\section{ACCURACY}

Accuracy was found by means of recovery experiments, by the determination of $\%$ mean recovery of sample at three different levels: $50 \%, 100 \%$, and $150 \%$. At each level, three determinations were carried out and $\%$ mean recovery was calculated.

\section{ASSAY}

Twenty tablets of acamprosate calcium (333 mg label claim) were taken and powdered. A measure equivalent to 73.19 $\mathrm{mg}$ was weighed and added to a $50 \mathrm{ml}$ volumetric flask, and the final volume was made up to $50 \mathrm{ml}$ with diluents and shaken for 5 minutes. The solution was filtered by Whatman filter paper. From the filtered solution, $0.5-2.5 \mathrm{ml}$ solution was added to $10 \mathrm{ml}$ volumetric flask to make a final volume up to $10 \mathrm{ml}$ using distilled water. 


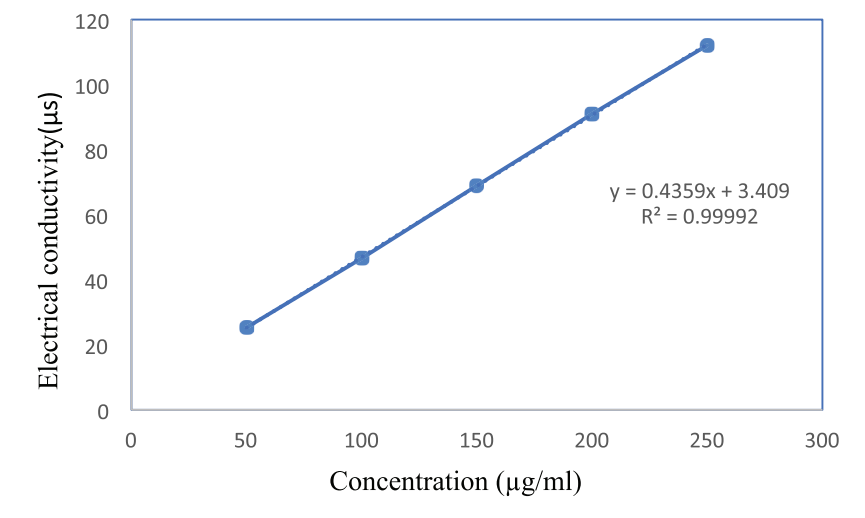

Figure 2. Standard calibration curve of acamprosate calcium at $250 \mathrm{~V}$.

\section{RESULT}

\section{Specificity}

The proposed method is specific as the conductance of water as a blank was found to be $1.75 \mu$ s and acamprosate calcium $(50 \mu \mathrm{g} / \mathrm{ml})$ solution showed a conductance of $25.28 \mu \mathrm{s}$. The results of the analysis were found to be specific and selective.

\section{Linearity}

The drug shows a linear relationship between electrical conductivity $(\mu \mathrm{s})$ verses drug concentration level. The results are shown in Figure 2. The equation of the straight line for acamprosate calcium is $y=0.4359 x+3.409$ and the regression coefficient is $R^{2}$ $=0.9999$.

\section{LIMIT OF DETECTION (LOD)/LIMIT OF QUANTIFICATION (LOQ)}

The LOD value obtained was $6.05 \mu \mathrm{g} / \mathrm{ml}$ and LOQ value was found to be $18.34 \mu \mathrm{g} / \mathrm{ml}$. Both results are in the acceptance range.

\section{PRECISION}

The precision indicating the value was precise and low, and $\%$ RSD is $<2 \%$. The results are given in Tables 1 and 2 .

Table 1. Intraday precision results of acamprosate calcium.

\begin{tabular}{ccccc}
\hline $\begin{array}{c}\text { Concentration } \\
(\boldsymbol{\mu g} / \mathbf{m l})\end{array}$ & $\begin{array}{c}\text { Conductance }(\boldsymbol{\mu s}) \\
(\overline{\boldsymbol{x}})\end{array}$ & $\begin{array}{c}\text { Standard } \\
\text { deviation }\end{array}$ & $\begin{array}{c}\text { \% Relative } \\
\text { standard } \\
\text { deviation }\end{array}$ \\
\hline \multirow{2}{*}{50} & 1 hour & $24 . .77$ & 0.12 & 0.48 \\
& 4 hours & 24.8 & 0.12 & 0.48 \\
& 8 hours & 25.31 & 0.21 & 0.82 \\
\multirow{2}{*}{150} & 1 hour & 67.77 & 0.605 & 0.89 \\
& 4 hours & 68.03 & 0.68 & 0.99 \\
& 8 hours & 69.92 & 0.18 & 0.25 \\
250 & 1 hour & 109.67 & 0.865 & 0.78 \\
& 4 hours & 109.73 & 0.165 & 0.15 \\
\hline & 8 hours & 111.47 & 0.435 & 0.39 \\
\hline
\end{tabular}

$\bar{x}=$ Mean conductance of three replicates.
Table 2. Interday precision results of acamprosate calcium.

\begin{tabular}{ccccc}
\hline $\begin{array}{c}\text { Concentration } \\
(\boldsymbol{\mu} \mathbf{g} / \mathbf{m l})\end{array}$ & $\begin{array}{c}\text { Conductance }(\boldsymbol{\mu s}) \\
(\overline{\boldsymbol{x}})\end{array}$ & $\begin{array}{c}\text { Standard } \\
\text { deviation }\end{array}$ & $\begin{array}{c}\text { \% Relative } \\
\text { standard } \\
\text { deviation }\end{array}$ \\
\hline \multirow{2}{*}{50} & 1st day & 24.68 & 0.11 & 0.44 \\
& 2st day & 24.36 & 0.14 & 0.57 \\
& 3rd day & 24.30 & 0.09 & 0.37 \\
\multirow{2}{*}{150} & 1st day & 69.01 & 0.265 & 0.38 \\
& 2st day & 68.01 & 0.83 & 1.22 \\
& 3rd day & 66.96 & 0.245 & 0.36 \\
\multirow{2}{*}{250} & 1st day & 108.06 & 0.17 & 0.15 \\
& 2st day & 107.9 & 0.1 & 0.09 \\
& 3rd day & 106.83 & 0.465 & 0.43 \\
\hline
\end{tabular}

$\bar{x}=$ Mean conductance of three replicates.

\section{RUGGEDNESS}

Ruggedness was carried out at different conditions to check the expected values from one analyst to another and the $\%$ RSD shows less than $2 \%$. The data of ruggedness are recorded in Table 3.

\section{ACCURACY}

Accuracy and recovery studies were carried out and the $\%$ mean recovery of the sample was recorded at three different levels: $50 \%, 100 \%$, and $150 \%$. Individual recovery and \%mean recovery were found to be greater than $98 \%$, which indicates that the method development is accurate and recovery values were in the range. The \%mean recovery values are shown in Table 4 .

\section{ASSAY}

The assay was carried out by using tablet formulation of label claim $333 \mathrm{mg}$ (ACAMPROL) and the values were obtained in an acceptable range. The results were in the range of $102 \%-$ $104 \%$.

\section{DISCUSSION}

In the present research work, an attempt has been made to develop a simple conductometric method. This method was found to be economic, simple, and rugged for estimation of

Table 3. Results of ruggedness for acamprosate calcium.

\begin{tabular}{ccccc}
\hline $\begin{array}{c}\text { Concentration } \\
(\boldsymbol{\mu g} / \mathbf{m l})\end{array}$ & $\begin{array}{c}\text { Conductance }(\boldsymbol{\mu s}) \\
(\overline{\boldsymbol{x}})\end{array}$ & $\begin{array}{c}\text { Standard } \\
\text { deviation }\end{array}$ & $\begin{array}{c}\text { \% Relative } \\
\text { standard } \\
\text { deviation }\end{array}$ \\
\hline \multirow{2}{*}{50} & Analyst 1 & 24.30 & 0.09 & 0.37 \\
& Analyst 2 & 24.49 & 0.02 & 0.08 \\
\multirow{2}{*}{150} & Analyst 1 & 66.96 & 0.245 & 0.36 \\
& Analyst 2 & 65.22 & 0.03 & 0.04 \\
\multirow{2}{*}{250} & Analyst 1 & 106.83 & 0.465 & 0.43 \\
& Analyst 2 & 102.7 & 0.1 & 0.09 \\
\hline
\end{tabular}

$\bar{x}=$ Mean conductance of three replicates. 
Table 4. Results of accuracy studies for acamprosate calcium.

\begin{tabular}{|c|c|c|c|c|c|c|c|}
\hline \multirow{2}{*}{$\begin{array}{l}\text { Total } \\
\text { conc. }\end{array}$} & \multirow{2}{*}{$\begin{array}{l}\text { Standard } \\
\text { conc. }\end{array}$} & \multirow{2}{*}{$\begin{array}{c}\text { Sample } \\
\text { conc. } \\
(\mu \mathrm{g} / \mathrm{ml})\end{array}$} & \multicolumn{2}{|c|}{ Conductance $(\mu s)$} & \multirow{2}{*}{$\begin{array}{c}\text { Concentration } \\
(\mu \mathrm{g} / \mathrm{ml})\end{array}$} & \multirow{2}{*}{$\begin{array}{c}\text { Sample conc. } \\
\text { different } \\
(\mu \mathrm{g} / \mathrm{ml})\end{array}$} & \multirow{2}{*}{$\begin{array}{c}\% \\
\text { Recovery }\end{array}$} \\
\hline & & & Standard & Sample & & & \\
\hline \multirow{3}{*}{$\begin{array}{c}75 \\
(50 \%)\end{array}$} & \multirow{3}{*}{$70(\mu \mathrm{g} / \mathrm{ml})$} & \multirow{3}{*}{$5(\mu \mathrm{g} / \mathrm{ml})$} & 36.95 & 37.25 & 75.60 & 5.60 & 112.17 \\
\hline & & & 36.84 & 37.11 & 75.54 & 5.54 & 110.9 \\
\hline & & & 36.99 & 36.95 & 74.91 & 4.91 & 98.37 \\
\hline \multirow{3}{*}{$\begin{array}{c}150 \\
(100 \%)\end{array}$} & \multirow{3}{*}{$70(\mu \mathrm{g} / \mathrm{ml})$} & \multirow{3}{*}{$80(\mu \mathrm{g} / \mathrm{ml})$} & 68.10 & 68.18 & 150.17 & 80.17 & 100.22 \\
\hline & & & 68.17 & 69.50 & 152.17 & 82.92 & 103.65 \\
\hline & & & 67.93 & 69.17 & 152.73 & 82.73 & 103.42 \\
\hline \multirow{3}{*}{$\begin{array}{c}225 \\
(150 \%)\end{array}$} & \multirow{3}{*}{$70(\mu \mathrm{g} / \mathrm{ml})$} & \multirow{3}{*}{$155(\mu \mathrm{g} / \mathrm{ml})$} & 100.6 & 101.2 & 226.34 & 156.34 & 100.86 \\
\hline & & & 100.3 & 102.6 & 230.15 & 158.15 & 102.03 \\
\hline & & & 100.8 & 102.3 & 228.34 & 158.34 & 102.16 \\
\hline
\end{tabular}

acamprosate calcium. The proposed method results and outcomes are compared with other research works published earlier on acamprosate calcium.

The literature survey reveals that acamprosate calcium can be analyzed by few chromatographic methods (Chabenat et al., 1987; Girault et al., 1990; Hammarberg et al., 2010). The published work has some limitation like use of costly solvents, hazardous chemicals, costly instruments, non-robust method, and longer time of analysis. Hence, in our proposed method, we have used water as a solvent which is universal and cheaper and the instrument cost is low. It is very simple in carrying out and is costeffective for the method developed and analysis.

All the values obtained in the method were found to be within the acceptance range as per the ICH norms.

UV-spectrophotometric trials were carried out with different solvents such as menthol, water, etc., but they did not get the peaks at the acceptable range and it showed less than $205 \mathrm{~nm}$ because the acamprosate calcium drug does not contain chromophore. Furthermore, it was carried on electrical conductometric meter and the linear regression coefficient value was found to be 0.9999 , Acamprosate calcium contains a cation charge and the solvent used was the distilled water. The method was developed on an electrical conductometric meter as this method is cheap, cost-effective, and no work has been reported on acamprosate calcium. The current method development and validation represent an alternative method in the laboratory which can be employed for routine analysis in the pharmaceutical industry.

\section{CONCLUSION}

The present research is a cost-effective, simple, and accurate electrical conductivity method for quantity estimation of acamprosate calcium in tablet dosage form developed as per the ICH guidelines. The method is economic, rapid, and does not need any sophisticated instruments. Hence, it may be employed for routine quality control analysis of acamprosate calcium in Active Pharmaceutical Ingrident (API) and marketed formulation.

\section{ACKNOWLEDGMENTS}

The authors are thankful to Principal Dr. S. S. Jalalpure for his support and guidance and to the Department of Pharmaceutical Chemistry, KLE College of Pharmacy. The authors are also thankful to Mr. Nikhil Gawas, Mr. Onkar S. Supe, and Ms. Sushmita Hiremath for help during the research work.

\section{ETHICAL APPROVAL}

Not applicable.

\section{CONFLICT OF INTEREST}

The authors declare that there is no conflict of interests.

\section{FUNDING}

This work did not receive any funds to declare from any national and international agency.

\section{REFERENCES}

Blanchin MD, Baalbaki B, Bosc N, Fabre H. Short-end injection technique in capillary electrophoresis for dissolution testing of tablets. Anal Chim Acta, 2000; 415(12):67-73.

Chabenat C, Ladure P, Blanc-Continsouza D, Boismare F, Boucly P. Determination of calcium acetylhomotaurinate by liquid chromatography with fluorimetric and electrochemical detection. J Chromatogr, 1987; 414:417-22.

Chabenat C, Ladure P, Moore N, Boucly P, Boismare F. Application of an analytical method to calcium acetylhomotaurinate determination in urine. Arzneimittelforschung, 1989; 39(11):1413-4.

Espino D, Cruz MP. Acamprosate calcium (Campral®): an effective treatment for maintaining abstinence in alcohol-dependent patients in combination with psychosocial support. Pharm Ther, 2005; 30(1):497-505.

Fabre H, Perrin C, Bosc N. Determination of homotaurine as impurity in calcium acamprosate by capillary zone electrophoresis. J Chromatogr A, 1999; 853(1-2):421-30.

Ghosh C, Jha V, Shinde CP, Chakraborty BS. A LC-MS analysis of acamprosate from humanplasma: pharmacokinetic application. Drug Test Anal, 2011; 3(10):735-42.

Girault J, Gobin P, Fourtillan JB. Determination of calcium acetyl homotaurinate in human plasma and urine by combined gas chromatography-negative-ion chemical ionization mass spectrometry. J Chromatogr, 1990; 530:295-305.

Hammarberg A, Beck O, Eksborg S, Jayaram-Lindström N, Lindefeldt A, Andersson M, Brundin L, Reid MS, Franck J. Acamprosate determinations in plasma and cerebrospinal fluid after multiple dosing measured by liquid chromatography-mass spectroscopy: a pharmacokinetic study in healthy volunteers. Ther Drug Monit, 2010; 32(4):489-96.

ICH Guidelines. Validation of analytical procedures: text and methodology. International Conference on Harmonization (ICH) Q2 (R1), Geneva, Switzerland, p 10, vol. 11, 2005. 
Kanala KM, Chandu BR, Hwisa NT, Khagga M, Katakam P, Challa BR. Quantification of acamprosate in human plasma By LC-ESIMS/MS with solid phase extraction: application to a bioequivalence study. J Pharm Res, 2013; 7(5):389-96.

Lipha Pharmaceuticals Inc. Briefing focument for acamprosate $333 \mathrm{mg}$ tablets. Food and Drug Administration, Washington, DC, pp 1-311, 2002.

Rhee YS, Park JH, Park S, Park CW, Ha JM, Jeong KW, Lee DS, Park ES. Analysis of acamprosate in beagle dog plasma By LC-MS-MS. Arch Pharm Res, 2008a; 31(8):1035-39.

Rhee YS, Park S, Lee TW, Park CW, Nam TY, Oh TO, Jeon JW, Lee DS, Park ES. Investigation of the relationship between in vitro and in vivo release behaviors of acamprosate from enteric-coated tablets. Arch Pharm Res, 2008b; 31(6):798-804.

Saivin S, Hulot T, Chabac S, Potgieter A, Durbin P, Houin G. Clinical pharmacokinetics of acamprosate. Clin Pharmacokinet, 1998; 35(5):331-45.

Umarov UA, Maslov OY, Kolisnyk SV, Fathullaeva M. Development and validation of the conductometric titration method of quantitative determination of free organic acids in the anise fruits. Eur $\mathrm{J}$ Mol Clin Med, 2020; 7(3):3874-83.

Xu F, Qing Y, Shang B, Liang M, Zou Y, Xu G. Pharmacokinetics of acamprosate calcium in healthy Chinese subjects after oral administration of three dosage levels. Arzneimittelforschung, 2009; 59(12):631-4.Zornoza T, Cano MJ, Polache A, Granero L. Pharmacology of acamprosate: an overview. CNS Drug Rev, 2003; 9(4):359-74.

\section{How to cite this article:}

Yadav RK, Maste MM, Surywanshi SS, Shastri U. Conductometric method development and validation to estimate acamprosate calcium in API and marketed formulation. J Appl Pharm Sci, 2021; 11(11):082-086. 